\title{
TRANSFORMASI PARADIGMA MANAJEMAN KEILMUAN SEKOLAH DASAR MENUJU PENDIDIKAN DASAR ISLAM
}

\author{
Zainal Anshari Marli \\ Institut Agama Islam Negeri (IAIN) Jember \\ zainalanshari@gmail.com
}

\begin{abstract}
Abstret
Islami Elementary School is combination Islamic education institution that was born from non formal education in Islamic boarding school formed as formal education of madrasah with elementary school as the continuing of Sekolah Rakyat (SR). This school is an elementary school formed by Dutch colonialist for the local students in Indonesia as the basic need of education. Sekolah Rakyat for the next transformation become elementary school created to make a combination the heritage of colonial education with the heritage of Indonesian Islamic education so that it is called Islamic Elementary School that still drive formal education mission and madrasah generally. Islamic Elementary School is a respond of muslim that shown by doing some innovation and creation of development of education institution in a complex society. Islamic elementary school not always using Islamic term, some of them stil use elementary school but the subject elaborate between elementary school and Madrasah Ibtidaiyah, so the content of this school become an Islamic Elementary School. It means the combination elementlary school with Madrasah Ibtidaiyah like Elementary Full Day School al-Baitul Amien Jember as the object focus of this paper.

Keywords: Transformation, Elementary School, Madrasah Ibtidaiyah, Islamic Elementary School.
\end{abstract}

\begin{abstract}
Abstrak
Sekolah Dasar Islam merupakan wujud perpaduan antara lembaga pendidikan Islam yang dilahirkan pendidikan non formal pondok pesantren berbentuk pendidikan formal madrasah dengan sekolah dasar yang merupakan perwujudan dari kelanjutan Sekolah Rakyat (SR), suatu sekolah dasar yang dibentuk oleh penjajah Belanda guna mewadahi putra-putri pribumi Indonesia dalam mewujudkan kebutuhan dasar bernama pendidikan. Sekolah Rakyat yang dalam transformasi berikutnya menjadi Sekolah Dasar ternyata di kreasi agar dapat dipadukan antara warisan pendidikan kolonial dengan warisan pendidikan Islam Indonesia, sehingga menjadi Sekolah Dasar Islam (SDI) yang tetap menjalankan misi pendidikan formal sebagaimana SD pada umumnya dan Madrasah Ibtidaiyah pada umumnya. Sekolah Dasar Islam merupakan respon yang ditampilkan umat Islam di dalam melakukan inovasi dan kreasi pada perkembangan lembaga pendidikan di tengah-tengah masyarakat. Sekolah Dasar Islam tidak mesti semuanya menggunakan kata atau istilah Islam, sebagian ada yang tetap menggunakan
\end{abstract}


kata Sekolah Dasar namun mata pelajarannya di elaborasi antara Sekolah Dasar dengan Madrasah Ibtidaiyah sehingga muatan mata pelajarannya menjadi Sekolah Dasar Islam, artinya perpaduan antara pelajaran Sekolah Dasar dengan Madrasah Ibtidaiyah, seperti SD Full Day School al-Baitul Amien Jember yang menjadi focus tulisan ini.

Kata kunci: Transformasi, Sekolah Dasar, Madrasah Ibtidaiyah, Sekolah Dasar Islam.

\section{Kontek Transformasi}

Akhir-akhir ini, tuntutan dan kebutuhan masyarakat akan pendidikan yang berkualitas semakin tinggi. Hal itu wajar, sejalan dengan perubahan waktu, dimana masyarakat selalu menginginkan yang terbaik dalam berbagai aspek. Baik dalam aspek pendidikan, ekonomi, politik, status sosial dan lain sebagainya. Sehingga untuk mencapai status social yang lebih baik, salah satu jalan utamanya adalah dengan memperbaiki proses pendidikan bagi anakanak mereka (red, masyarakat).

Dalam tulisan ini, ingin menguraikan salah satu kebutuhan masyarakat Jember Jawa Timur akan pendidikan yang semakin berkualitas dari waktu-kewaktu. Masyarakat Jember mayoritas penduduknya beragama Islam, lapisan kedua dan berikutnya ada Kristen Katolik dan Protestan, ada juga masyarakat penganut agama Hindu, Budha, Konghucu dan aliran kepercayaan. Bahkan gambaran akan kebutuhan pendidikan tersebut dapat dilihat dari data lembaga pendidikan yang dimiliki oleh Kabupaten Jember sebagai berikut.

Kabupaten Jember memiliki sekitar 750 pendidikan pondok pesantren, dengan komposisi tempat ibadah berupa Masjid sekitar 2.000 Masjid, dan 4.000 Musholla (red, Islam), Gereja di Jember sebanyak 80 dan 14 di antaranya berada di perkotaan (red, Kristen), sekitar 17 Pura (red, Hindu), dengan Vihara sebanyak 2 buah (red, Budha) dan Klenteng sebanyak 2 buah (red, Konghuchu). Sedangkan lembaga pendidikan dapat kita lihat data berikut, pendidikan dasar sekitar 1.434 (MI-SD swasta dan negeri) mulai dari sekolah negeri, sekolah yang berafiliasi dengan ormas Islam seperti NU, Muhammadiyah, al-Irsyad al-Islamiyah bahkan sekolah yang berafiliasi dengan salah satu partai politik tertentu. Ada juga sekolah dasar yang berafiliasi dengan Kristen Katolik dan Protestan dan semacamnya.

Jember juga memiliki 517 Sekolah Menengah Pertama (MTs-SMP) swasta dan negeri. Demikian juga afiliasinya dengan berbagai ormas keagamaan sebagaimana sekolah dasar di atas. Sekitar 100 Sekolah Menenagah Atas (MA- SMA) swasta dan negeri serta 91 Sekolah 
Menenagah Kejuruan, mulai dari SMK swasta juga SMK Negeri, 23 Perguruan Tinggi (PT) negeri dan swasta, jumlah kuantitatif tersebut terus bertambah setiap tahunnya. ${ }^{1}$

Namun yang akan menjadi fokus tulisan ini adalah kebutuhan masyarakat akan pendidikan dasar Islam pada masa sekarang. Setidaknya, ada beberapa sekolah dasar Islam yang banyak diminati oleh masyarakat Jember, yakni Sekolah Dasar Full Day School al-Baitul Amien, SD al-Irsyad al-Islamiyah, SD al-Furqan dan SDIT Lukman Hakim, keempat sekolah dasar ini mulai melampui minat masyarakat kepada Madrasah Ibtidaiyah (MI) di Jember. Sebelum beberapa sekolah itu muncul, terlebih dahulu ada Madrasah Ibtidaiyah (MIMA) KH. Shiddiq (Jl. KH. Shiddiq Talangsari Jember) yang dari dulu sampai hari ini tetap sangat diminati oleh masyarakat muslim Jember.

Namun sejalan dengan perjalanan waktu, keberadaan keempat sekolah dasar tersebut sangat diminati oleh masyarakat, salah satu indikatornya adalah tingginya permintaan orang tua siswa untuk menyekolahkan putra-putrinya di lembaga tersebut. Bahkan untuk Sekolah Dasar Full Day School al-Baitul Amien lebih awal melakukan penerimaan peserta didik baru dibandingkan dengan sekolah-sekolah yang lain. Selain akan menjadi fokus dalam tulisan ini, penulis akan menyampaikan hal-hal yang berkaitan dengan inovasi Sekolah Dasar Full Day School al-Baitul Amien dalam melakukan proses pendidikan dan pembelajaran. Sehingga keberadaan Sekolah Dasar Full Day School al-Baitul Amien melampui minat masyarakat kepada madrasah ibtidaiyah.

\section{Mencermati Sekolah Dasar Islam}

Sebagaimana ditulis pemikir pendidikan Islam, Prof. Abd. Halim Soebahar, sekolah dasar Islam memiliki makna yang sama dengan sekolah dasar pada umumnya, secara khusus dalam praktek pembelajarannya. Sebab, istilah tersebut merujuk pada lembaga pendidikan pada tingkat dasar dan menengah. Dalam pendidikan Islam dikenal istilah madrasah, (MI, MTs, MA, MAN, MAPK) dalam pendidikan yang bercorak eropa dikenal istilah sekolah, ini adalah fenomena pendidikan di Indonesia yang diakibatkan oleh salah satu faktor penjajahan Belanda. $^{2}$ Kami memahami bahwa sekolah dasar (SD) yang awal mulanya sekolah rakyat (SR) bertransformasi guna mewujudkan harapan masyarakat yang begitu tinggi kepada pen-

\footnotetext{
${ }^{1}$ Moch. Ichsan dan Zainal Anshari, Sejarah Masjid Jami' Al-Baitul Amien Jember; Mengurai Peran Dan Kontribusinya, (Jember: Superior, 2017), 1-19.

2 Abd. Halim Soebahar, Modernisasi Pesantren; Studi Transformasi Kepemimpinan Kiai Dan System Pendidikan Pesantren, (Yogyakarta: LKIS, 2013), 11-27.
} 
didikan. Setelah sekolah dasar ada juga sekolah menegah pertama (SMP) dan sekolah menenengah atas dalam bentuk SMA dan SMK. ${ }^{3}$

Jika dilihat dari aspek tujuan adanya transformasi pendidikan Islam di atas, maka dapat mengacu kepada gagasan yang pernah ditulis oleh al-Ghazali, sebagaimana ditulis oleh Ainur Rafik sebagai berikut; "tujuan pendidikan Islam sebenarnya hanya ada dua, walaupun sebenarnya hanya ada satu tujuan, yaitu kesempurnaan manusia dalam mendekatkan diri kepada Allah Swt dan untuk mewujudkan kesempurnaan kebahagiaan dunia dan akhirat. ${ }^{4}$

Masih dalam ulasan Prof. Abd. Halim Soebahar, selama ini, Sekolah Dasar yang bercirikan khas keagamaan dan keislaman dianggap oleh sebagian kalangan, sebagai lembaga pendidikan yang mutunya lebih rendah daripada mutu lembaga pendidikan pada umumnya, terutama sekolah umum, walaupun ada beberapa fakta, Madrasah Ibtidaiyah dalam bentuk sekolah dasar Islam lebih maju daripada sekolah umum. ${ }^{5}$ Namun, keberhasilan Sekolah Dasar Islam masih dalam jumlah yang terbatas dan belum mampu menghapus kesan negatif yang melekat pada dirinya. ${ }^{6}$

Sebagaimana hasil pembicaraan penulis dengan salah satu wali murid SD Full Day School al-Baitul Amien Jember, pada pertengahan tahun 2016, tentang alasan memilih SD Full Day School al-Baitul Amien, ternyata karena kelebihan dan kemampuan anak dalam menghafalkan, memahami dan mengamalkan dasar-dasar ajaran agama Islam dalam kehidupan sehari-hari. ${ }^{7}$ Inilah yang dalam teori pendidikan mutakhir disebut dengan mutu. ${ }^{8}$ Mutu pendidikan pada sekolah dasar Islam merupakan salah satu tujuan pendidikan yang dicari dan diminati oleh stake holder pendidikan (masyarakat), dalam hal ini oleh para orang tua. Setidaknya ada empat tehnik dalam mengaplikasikan peningkatan mutu, di antaranya, shool review, benchmarking, quality assurance, dan quality control. Hal ini sebagaimana dirumuskan dalam ketetapan pemerintah pusat Departeman Pendikan Nasional 2000.

Mutu pendidikan yang berkualitas, merupakan suatu hal yang tidak dapat dielakkan, sebagai suatu keinginan dari masyarakat yang terus mengalami pertumbuhan dan perkembangan dalam menjawab kebutuhan hidupnya. ${ }^{9}$ Satu-satunya cara mengapa SD Full

\footnotetext{
${ }^{3}$ Ainur Rafik, Pendidikan Islam Dalam Sisdiknas, (Jember: STAIN Jember Press), 2013.

${ }^{4}$ Ainur Rafik, Pendidikan Islam Dalam Sisdiknas, (Jember: STAIN Jember Press, 2013), 24.

${ }^{5}$ Abd. Halim Soebahar, Matriks Pendidikan Islam, (Yogyakarta: Pustaka Marwa, 2009), 11-28.

${ }^{6}$ Mujammil Qomar, Dimensi Manajemen Pendidikan Islam, (Jakarta: Emir-Erlangga, 2015), 340-347.

${ }^{7}$ Leny Marinda, "implementasi pembelajaran Full Day School dalam meningkatkan kecerdasan social peserta didik di SD al-Baitul Amien Jember”, (skripsi tidak dipublikasikan, Jember: STAIN Jember, 2011).

${ }^{8}$ Edward Sallis, Total Quality Management in Education, (Yogyakarta: IRCiSoD), 2011.

${ }^{9}$ Suhadi Winoto, Manajemen Berbasis Sekolah, (Jember: Pena Salsabila, 2011), 86-89.
} 
Day School al-Baitul Amien Jember begitu tinggi diminati masyarakat, karena mampu menjamin kualitas yang "lebih" jika dibandingkan dengan sekolah atau madrasah pada umumnya di Jember.

Dalam perkembangannya di Indonesia, keberadaan Sekolah Dasar Islam telah diintegrasikan dalam Sistem Pendidikan Nasional (lihat sisdiknas No 20 tahun 2003). ${ }^{10}$ Dalam kajian Abd. Halim Soebahar, kenyataan di atas dapat dilihat dalam keputusan Menteri Agama Republik Indonesia Nomor 372 tentang Kurikulum Pendidikan Dasar Bercirikan Khas Agama Islam. Dalam Peranturan Menteri tersebut diatur bahwa Madrasah melaksanakan Kurikulum Nasional seperti di Sekolah Dasar dan sekolah Lanjutan Tingkat Pertama. Dalam hal ini Kurikulum Sekolah Dasar Islam memuat mata pelajaran yang ada di SD dan SMP pada umumnya. Dalam hal ini, berarti Madrasah Ibtidaiyah bertransformasi menjadi Sekolah Dasar dengan tetap membawa muatan mata pelajaran agama Islam yang selama ini menjadi ciri khas Madrasah Ibtidaiyah di Indonesia. ${ }^{11}$

Dalam pengamatan penulis, sekolah dasar Islam, merupakan wujud penerimaan komunitas muslim terhadap model pendidikan yang dibawa dari luar Indonesia, namun tetap menampilkan nilai-nilai keislamannya sebagai wujud mempertahankan nilai keberagamaan dalam sebuah lembaga pendidikan hasil ramuan masyarakat Indonesia yang selalu lekat dengan nilai-nilai keagamaan.

Sekolah Dasar atau SD Full Day School al-Baitul Amien merupakan salah satu sekolah dasar yang bercirikan khas keislaman, dengan minat yang cukup tinggi dari masyarakat, baik oleh masyarakat Jember sendiri maupun oleh masyarakat yang berada di sekitar kabupaten Jember. Berdasarkan hasil kajian dan observasi yang penulis lakukan secara langsung di SD Full Day School al-Baitul Amien, didapatkan sebuah gambaran, minat para orang tua kepada sekolah dasar Islam yang berada di jantung kota Jember tersebut, karena kualitas bacaan dan pemahaman alQuran peserta didik serta dasar-dasar keagamaan Islam pada umumnya. ${ }^{12}$ Hal tersebut sangat memungkinkan karena SD Full Day School al-Baitul Amien berada di lokasi di tengah-tengah pusat kota dan menempati masjid bersejarah yang pernah di rehab pada tahun $1934 \mathrm{M}$ yang dimiliki masyarakat Jember. ${ }^{13}$

Di samping perkembangan lembaga pendidikan, keberadaan pendidikan sebagai sebuah upaya untuk mencerdaskan kehidupan bangsa, sebagai mana yang tertuang dalam

\footnotetext{
${ }^{10}$ Sisdiknas nomor 20 tahun 2003 tentang system pendidikan nasional Indonesia.

${ }^{11}$ Lihat juga dalam Karel A. Steenbrink, Pesantren, Madrasah, Sekolah Pendidikan Islam dalam Kurun Modern, (Jakarta: LP3ES, 1974)

${ }^{12}$ Observasi dan wawancara kepada bapak Rifan Humaidi dan ibu Nurul, Januari - Juni 2016.

${ }^{13}$ Moch. Ichsan dan Zainal Anshari, Sejarah Masjid Jami’ Al-Baitul Amien Jember.., 1-19.
} 
pembukaan UUD 1945, semangat untuk memajukan pendidikan di Indonesia sudah menggugah semua institusi pendidikan. Baik keluarga, sekolah, masyarakat dan khusunya birokrasi. Banyak dari mereka yang semakin antusias memperhatikan wajah pendidikan di Negeri ini. Realitas ini tentu berbeda dengan masyarakat pada tahun 1940-an, dalam tahun 50an, 60-an, 70-an, 80-an, 90-an sampai 2000-an memasuki belasan, minat masyarakat semakin tidak terbendung kepada pendidikan yang dalam menyediakan mutu atau kualitas semakin baik, sehingga terlihat adanya persaingan antar sekolah dan madrasah untuk meningkatkan kualitas peserta didiknya, bahkan sampai terdapat beberapa sekolah dan madrasah yang memasang label sekolah unggulan, sekolah bertaraf nasional, sekolah bertaraf internasional, hal ini tentu saja bagian dari strategi bersaing atau marketing pendidikan yang tidak dapat dihindari.

Pendidikan menjadi tanggung jawab bersama, antara orang tua, masyarakat dan pemerintah. Berdasarkan tanggung jawab tersebut, maka perbaikan kualitas pendidikan di Indonesia menjadi tanggung jawab besar orang tua, masyarakat dan pemerintah. Oleh sebab itu, selanjutnya pemerintah, orang tua dan masyarakat menggalang kekuatan baru yang disebut dengan Komite Madrasah dalam rangka meningkatkan mutu pendidikan disebuah sekolah atau madrasah, baik sekolah umum maupun swasta. ${ }^{14}$ Namun pada dasarnya, sekolah dasar Islam atau madrasah dalam Islam dapat melakukan kreasi dan inovasi pendidikan, baik pada aspek manajemen, kurikulum, pengembangan sarana-prasarana, peningkatan kualitas sumber daya manusia dan sebagainya, namun tetap berpijakan kepada dasar fundamental yakni al-Quran, al-Hadist dan ijtihad. ${ }^{15}$

\section{Pendidikan dan Pijakan Fundamental}

Upaya pemerintah untuk peningkatan mutu, pemerataan, efisiensi dan penyelenggaraan pendidikan Nasional perlu dukungan dari semua stakeholder yang ada, serta keseriusan dan kesungguhan pemerintah untuk peningkatan kualitas pendidikan. Keseriusan tersebut dapat digambarkan dengan digantinya Undang-Undang Nomor 02 Tahun 1989 tentang Sistem Pendidikan Nasional menjadi Undang-Undang Nomor 20 Tahun 2003 tentang Sistem Pendidikan Nasional. Karena Undang-Undang Nomor 02 tahun 1989 tentang system pendidikan nasional dianggap tidak memadai dan kurang relevan lagi. Bahkan, perlu

\footnotetext{
${ }^{14}$ Suhadi Winoto, Manajemen Berbasis Sekolah, (Jember: Pena Salsabila, 2011), 134-144.

${ }^{15}$ Ainur Rafik, Pendidikan Islam Dalam Sisdiknas, (Jember: STAIN Jember Press, 2013), 13-19.
} 
disempurnakan, agar sesuai dengan amanat perubahan Undang-Undang Dasar $1945 .{ }^{16}$ Bentuk tanggung jawab bangsa dalam membentuk watak masyarakat yang sesuai dengan amanah Undang-Undang Dasar 1945 diperluas lagi dengan Undang-Undang baru, sehingga peran dan fungsi ini lebih futuristik dibandingkan dengan peran sebelumnya.

Dalam pengamatan penulis, transformasi madrasah ibtidaiyah menjadi sekolah dasar Islam merupakan bagian dari strategi bersaing dalam konteks melakukan penyesuaian dengan kebutuhan masyarakat. Dalam kaidah disebutkan, al muhafadhatu al qadi as sholih wal akhdu bi al jadidi al ashlah, jika diberi makna bebasnya adalah sebagai berikut, menjaga tradisi (nilai) lama yang masih baik dan mengadopsi nilai baru (tradisi baru) yang lebih baik. Inilah yang dalam kajian Ainur Rafik menyatakan bahwa dasar fundamental pendidikan Islam mengacu kepada al-Quran, al-Hadis dan ijtihad. Dalam artian, bentuk lembaga pendidikannya berubah secara institutive, namun substansi yang menjadi muatan mata pelajaran tetap dipertahankan, karena adanya tuntutan dan permintaan dari masyarakat. Sebagai lembaga pendidikan formal, maka sekolah dasar Islam tetap berpijak kepada UU nomor 20 tahun 2003 tentang system pendidikan nasional. Namun secara substansi mata pelajaran, sekolah dasar Islam tetap berpijak kepada ajaran al-Quran, al-Hadist yang memberi tuntunan beribadah kepada Allah Swt untuk mewujudkan kesempurnaan hidup di dunia dan akhirat.

\section{Marketing Pendidikan}

Diakui atau tidak, dunia pendidikan mutakhir juga tidak dapat dipisahkan dari marketing pemasaran pendidikan, yang paling banyak melakukan marketing dengan kemasan yang paling menarik dan paling menjanjikan, maka ia akan meraih kuantitas dan kualitas peserta didik yang semakin bagus. Secara mendasar, teori marketing pendidikan yang akan dilakukan kepada dunia pendidikan setidaknya berpijak kepada teori-teori dasar pemasaran secara umum. Moch. Chotib menjelaskan secara singkat, manajemen pemasaran dapat digambarkan sebagai berikut; a) mengukur keinginan pasar/masayarakat sebagai pelanggan, b) mendorong terciptanya barang/ jasa yang dapat memenuhi keinginan masyarakat, c)menyampaikan keunggulan barang/produk yang dihasilkan, d) mendistribusikan barang kepada masyarakat. ${ }^{17}$ Jika prinsip-prinsip dasar dalam dunia pemasaran ini dapat diwujudkan

\footnotetext{
${ }^{16}$ Abd. Halim Soebahar, Matrik Pendidikan Islam.., 34

${ }^{17}$ Moch. Chotib, Pesantren Dan Masyarakat Transformatif, (Jember: Pena Salsabila, 2010), 9-10. Bandingkan juga dengan penulis yang sama Moch. Chotib, Cakrawala Pesantren; Melacak Geneologi Pendidikan Pesantren, (Jember: Pena Salsabila, 2010).
} 
kepada dunia pendidikan, maka diyakini, lembaga pendidikan yang dimaksud akan diminati oleh masyarakat sebagai pengguna jasa pendidikan.

Selain itu, dalam teori Total Quality Managemen in Education (TQM), peserta didik diibaratkan barang. Untuk menghasilkan out put yang baik, maka diperlukan bahan dasar yang baik, proses yang mapan, evaluasi yang sesuai dengan standart, dan pengukuran kualitas dengan kebutuhan pasar / masyarakat. ${ }^{18}$ Dalam dunia pendidikan, kualitas tentu saja tidak hanya diukur secara fisik, tapi juga secara psikologis. Sebagai bagian dari proses ijtihad dalam mengembangkan pendidikan Islam, menurut hemat penulis hal ini masih abash dilakukan, senyampang tidak keluar dari tujuan yang paling mendasar dari dilaksanakannya pendidikan nasional dan pendidikan Islam secara bersamaan.

Sekolah Dasar atau SD Full Day School al-Baitul Amien Jember banyak menyedot perhatian masyarakat muslim yang peduli akan peningkatan kualitas pendidikan. Pada umumnya, masyarakat perkotaan kurang antusias dengan sekolah-sekolah yang berlabelkan agama tertentu apalagi masih berbunyi Madrasah Ibtidaiyah (red, contoh sebagian kasus di Indonesia). Namun tidak demikian dengan Sekolah Dasar atau SD Full Day School al-Baitul Amien Jember, minat masyarakat begitu tinggi bahkan antara permintaan dan penyediaan fasilitas pendidikan lebih tinggi permintaan, sehingga Yayasan Masjid al-Baitul Amien sebagai penyedia jasa pendidikan dasar, agak sedikit kesulitan menjawab keinginan para orang tua yang begitu antusias, karena minimnya fasilitas yang dimiliki Masjid Jami’ al-Baitul Amien Jember. Realitas ini menunjukkan, ternyata masyarakat memiliki minat yang begitu tinggi kepada pendidikan Islam dengan catatan mampu melakukan pengkemasan dan marketing yang berkelanjutan dan sesuai dengan harapan masyarakat pengguna jasa pendidikan.

Bahkan para orang tua tidak saja menginginkan putra-putrinya hanya sekolah setingkat SD saja, banyak dari mereka yang menginginkan keberlanjutan putra-putrinya hingga SMP dan SMA di al-Baitul Amien, walaupun hingga detik ini, Yayasan masjid jami' al-Baitul Amien belum mampu menjawab keinginan masyarakat tersebut dengan menyediakan sarana pendidikan setingkat SLTA. Walaupun ada pembahasan untuk membuka pendidikan SLTA dan Perguruan Tinggi Ilmu al-Quran namun hingga detik ini, keinginan tersebut belum dapat terealisasikan dengan baik. Sampai sejauh ini, Yayasan masjid jami’ al-Baitul Amien masih mampu menyediakan pendidikan dasar mulai dari Taman Penitipan Anak (TPA), Pendidikan Anak Usia Dini (PAUD), Taman Kaka-Kanak (TK), Taman Pendidikan al-Quran (TPA-TPQ), Sekolah Dasar (SD) dan Sekolah Menengah Pertama (SMP).

\footnotetext{
${ }^{18}$ Edward Sallis, Total Quality Management in Education, (Yogyakarta: IRCiSoD, 2011).103
} 
Selain lembaga pendidikan formal, Masjid Baitul Amien juga menyediakan pendidikan non formal bagi generasi muda agar senang dan cinta kepada masjid dengan menyediakan organisasi remaja masjid yang cukup berperan dalam pengembangan pendidikan al-Baitul Amien karena dapat mensuplai guru-guru professional selain itu juga dapat melahirkan kader-kader masjid yang tangguh dalam merealisasikan nilai dan ajaran Islam yang moderat atau Islam yang bernilai rahmatan lil alamin. ${ }^{19}$ Dari realitas tersebut, penulis membayangkan, seandainya Jember dengan kuantitas 2.000 masjid yang dimiliki, mampu menyediakan pendidikan sebagaimana al-Baitul Amien maka tentu akan menjadi bukti bahwa masjid bukan hanya mampu menyediakan pendidikan non formal, tapi juga dapat menyediakan pendidikan formal yang berkualitas.

Sekolah Dasar Islam (SD Full Day School al-Baitul Amien Jember) yang banyak diminati masyarakat muslim Jember tersebut, masih terhitung sangat muda jika dibandingkan dengan usia madrasah ibtidaiyah atau sekolah dasar pada umumnya. Bahkan kepemimpinan kepala sekolah yang menahkodai sekolah tersebut masih terhitung sangat sedikit, mulai dari Iskandar Nur Hidayat, Misrawi, Akhmad Hafid sampai saat ini Hizbullah Muhib. ${ }^{20}$ Namun jumlah secara kuantitas peserta didik yang bergabung belajar di dalamnya setiap tahun selalu mengalami peningkatan. Bahkan kini teklah di buka SD 2 Full Day School al-Baitul Amien Jember yang beralamat di Jl. Imam Bonjol Kaliwates Jember berhadapan dengan MAN 1 Jember. tentu saja hal ini merupakan salah satu contoh transformasi pendidikan dasar Islam yang dengan sangat baik menampung kepercayaan masyarakat muslim Jember. Penulis melihat, ini adalah kemampuan atau keberhasilan dalam melakukan adaptasi terhadap teori pendidikan Islam klasik, Islam modern dan ilmu-ilmu marketing dalam dunia industri, diramu dan disajikan dalam ruang lingkup pengembangan pendidikan Islam.

\section{Inovasi SD Full Day School Al-Baitul Amien Jember}

Melihat realitas dan keinginan masyarakat yang sedemikian rupa, perkembangan pendidikan dengan segala dinamika yang menyertainyapun tidak ayal dirasakan oleh lembaga pendidikan di bawah naungan yayasan pendidikan Islam, termasuk Sekolah Dasar atau SD Full Day School al-Baitul Amien Jember. Apalagi dengan diberlakukannya otonomi daerah. Dengan semangat desentralisasi yang melanda segala lini birokrasi, lembaga pendidikan sebagai bagian dari bangsa juga menempati ruang sendiri untuk mengatur tata kelola rumah tangganya sendiri sesuai dengan Undang-Undang dan Peraturan Pemerintah yang mengaturnya. Dalam

\footnotetext{
${ }^{19}$ Zainal Anshari, Anak Muda Masjid Membangun Negeri; Kisah-Kisah Unik Remaja Masjid Al-Baitul Amien, (Surabaya: Pustaka Radja, 2016).

${ }^{20}$ Moch. Ichsan dan Zainal Anshari, Sejarah Masjid Jami’ Al-Baitul Amien Jember.., 111.
} 
kontek ini, tentu lembaga pendidikan harus bersaing memasarkan kualitas out put atau kualitas proses, sehingga dipercaya dan pada akhirnya permintaan dari masyarakat semakin tinggi akan lembaga pendidikan tersebut.

Sebagai lembaga pendidikan dasar yang bercirikan khas agama Islam, Sekolah Dasar atau SD Full Day School al-Baitul Amien Jember memiliki segudang prestasi yang tidak kalah dengan sekolah-sekolah dasar yang bercirikan umum. Apalagi jika khusus dibandingkan dengan sekolah-sekolah dasar yang bercirikan khas agama Islam di Jember, Sekolah Dasar atau SD Full Day School al-Baitul Amien Jember masih terhitung sangat unggul sebagai sekolah dasar yang dapat bersaing dalam mengembangkan bakat dan minat serta dapat mengembangkan kualitas pendidikan, pengajaran dan pembelajarannya. ${ }^{21}$

Sehingga dengan tingginya permintaan dari masyarakat kepada Sekolah Dasar atau SD Full Day School al-Baitul Amien Jember, maka tentu saja akan menarik untuk mendorong tumbuh kembangnya lembaga pendidikan yang bersumber dan berpusat di masjid. Sehingga semakin nampak peran masjid sebagai tempat ibadah sekaligus sebagai tempat pelaksanaan dan pelestarian pendidikan Islam di tengah-tengah masyarakat. Pendidikan Islam memeiliki filsafat yang berorientasi kepada dua arah sekaligus, yaitu arah duniawi dan arah ukhrawi. Disinilah letak perbedaannya dengan pendidikan Eropa dan sekuler yang meniadakan tujuan ukhrawi. ${ }^{22}$ Pendidikan Eropa yang melulu mengedepankan aspek-aspek duniawi memiliki beberapa capaian yang luar biasa, namun demikian kata Prof. Masdar Hilmy pendidikan Indonesia perlu berkaca kepada mereka (red, Eropa) guna mencapai prestasi yang lebih gemilang. ${ }^{23}$

Dalam beberapa hal, penulis setuju dengan Prof. Masdar Hilmy, adakalanya kita perlu banyak belajar kepada Eropa, walaupun dalam hal-hal tertentu kita juga perlu mempertahankan nilai-nilai pendidikan yang sudah sejak lama melekat kepada bangsa Indonesia. Etika dalam pemaknaan filsuf muslim, perlu dipertahankan dalam peradaban masyarakat muslim Indonesia, namun dalam hal pengembangan ilmu dan sains kita perlu belajar kepada sispapun dan Negara manapun, guna mewujudkan generasi yang lebih cemerlang. ${ }^{24}$

Pendidikan Islam, merupakan suatu model pendidikan yang menyiapkan peserta didiknya secara komprehensip. Oleh karenanya, di beberapa daerah, model pendidikan Islam sangat diminati oleh masyarakat, khsusunya masyarakat perkotaan. Di Jakarta ada SD al-Azhar, di Sura-

\footnotetext{
${ }^{21}$ Leny Marinda, “implementasi pembelajaran Full Day School dalam meningkatkan kecerdasan social peserta didik di SD al-Baitul Amien Jember”, (skripsi tidak dipublikasikan, Jember: STAIN Jember, 2011).

${ }^{22}$ Abd. Haris dan Kivah Aha Putra, Filsafat Pendidikan Islam, (Jakarta: Amzah, 2012). 19

${ }^{23}$ Masdar Hilmy, Pendidikan Islam dan Tradisi Ilmiah, (Malang: Madani, 2016), 101-112.

${ }^{24}$ Endang Saifuddin Anshori, Ilmu, Filsafat Dan Agama, Pendahuluan Pendidikan Agama Islam Di Perguruan Tinggi, (Surabaya: PT. Bina Ilmu, 1990), 33-35.
} 
baya ada SD al-Hikmah, SD al-Falah dan semacamnya, di Malang ada SD Sabilillah dan termasuk di Jember ada SD Full Day School al-Baitul Amien, SD Darus Sholah, MI Unggulan NURIS, dan MIMA KH. Shiddiq, beberapa sekolah Islam di Jember merupakan suatu tempat pendidikan yang sangat tinggi menerima permintaan dari masyarakat, di Jember misalkan PAUD, TK dan SD 1 dan SD 2 al-Baitul Amien, termasuk juga di dalamnya SMP al-Baitul Amien Jember, dan yang unik, taman pendidikan al-Quran (TPA-TPQ) al-Baitul Amien Jember juga sangat tinggi menerima permintaan dari masyarakat muslim Jember dan sekitarnya.

Secara spesifik inovasi yang dilakukan oleh sekolah-sekolah Baitul Amien secara khusus yang dilakukan SD Full Day School al-Baitul Amien adalah sebagai berikut; 1) senyum pagi dan senyum sore, dalam hal ini, guru datang kesekolah lebih awal dibandingkan dengan murid SD, sebelum siswa hadir di sekolah, guru piket sudah terlebih dahulu datang, mereka menyambut dan sambil menyapa dengan senyum dan salam di depan pintu sekolah, mereka juga bertanya kondisi kesehatan murid begitu pula dengan keluarganya, sehingga siswa sangat respek kepada guru dan sekolah dimana ia belajar. 2) program donasi social, sekolah menyelenggarakan iuran atau sumbangan sukarela, baik di tingkatan siswa maupun guru untuk disalurkan kepada masyarakat fakir miskin, anak yatim, janda tua dan masyarakat yang sangat membutuhkan, pada mata pelajaran tertentu, siswa diajak menyalurkan langsung sumbangan tersebut, sehingga tertanam kecerdasan social atau kepedulian social peserta didik, 3) home visite atau kunjungan guru ke rumah siswa yang bermasalah, guru langsung datang menemui wali murid siswa yang bermasalah, mengkaji problem yang muncul pada anak serta mencarikan solusinya bersama dengan wali murid, 4) penggunaan kurikulum diknas disertai dengan kurikulum khas pendidikan Islam berbasis masjid, 5) studi kasus dan kunjungan kepada masyarakat tertentu yang menjadi objek mata pelajaran, dan 6) promosi prestasi akademik dan non akademik siswa.

Inivasi yang dilakukan oleh SD Full Day School al-Baitul Amien ini merupakan perwujudan dari respon pendidikan Islam terhadap tuntutan masyarakat yang semakin beragam dan kompleks. Inovasi tersebut tentu saja masih banyak, misalkan perbaikan sarana dan prasarana, peningkatan kualitas sumber daya manusia guru dan pelayanan yang cukup memadai kepada masyarakat (service), khususnya kepada wali murid, baik dalam bentuk layanan informasi, layanan konseling, layanan parenting dan lain sebagainya. Ini adalah beberapa model inovasi pengembangan pendidikan Islam agar dapat diterima oleh masyarakat pada berbagai lapisan.

Tulisan ini tentu saja sebagai kajian yang belumlah sempurna, karena hanya melakukan studi pada satu lembaga pendidikan dasar saja. Namun demikian, sebagai sebuah sumbangsih 
dalam proses transformasi, inovasi dan mengkreasi pendidikan dasar Islam untuk menjadi lebih baik, tidak ada salahnya untuk disampaikan kepada public pembaca.

\section{Kesimpulan}

Kesimpulan tulisan berikut ini, yakni transformasi pendidikan dasar Islam dalam mewujudkan generasi emas dapat diuraikan sebagai berikut; pendidikan yang diminati masyarakat tentu tidak akan lepas dari namanya kualitas atau produk yang dihasilkan. Produk yang dihasilkan juga tidak boleh lepas dari inovasi-inovasi yang dapat menarik minat masyarakat, sehingga kualitas atau produk (SDM peserta didik) yang dihasilkan sebuah lembaga pendidikan akan menjadi pemikat bari para pengguna fasilitas pendidikan, yakni masyarakat itu sendiri.

Secara spesifik inovasi yang dilakukan oleh SD Full Day School al-Baitul Amien adalah sebagai berikut; 1) senyum pagi dan senyum sore, dalam hal ini (guru menyambut di sekolah sebelum siswa hadir di sekolah dan guru mengantar hingga di depan gerbang sebelum siswa pulang kerumah). 2) program donasi sosial, guna meningkatkan kecerdasan sosial peserta didik, 3) home visite atau kunjungan guru ke rumah siswa yang bermasalah, guna mencarikan solusinya bersama dengan wali murid, 4) perpaduan kurikulum diknas disertai dengan kurikulum khas pendidikan Islam berbasis masjid, 5) studi kasus dan kunjungan kepada masyarakat tertentu yang menjadi objek mata pelajaran, dan 6) promosi prestasi akademik dan non akademik siswa. Tentu saja dalam tulisan ini tidak dapat mengekspresikan segala inovasi atau segala sesuatu yang dilakukan oleh SD Full Day School al-Baitul Amien guna transformasi pendidikan dasar Islam dalam mewujudkan generasi emas sebagaimana menjadi tema besar dalam tulisan kali ini. 


\section{DAFTAR PUSTAKA}

Zainal, Anshari. 2016. Anak Muda Masjid Membangun Negeri; Kisah-Kisah Unik Remaja Masjid Al-Baitul Amien, Surabaya: Pustaka Radja.

Saifuddin, Anshori, Endang. 1990. Ilmu, Filsafat Dan Agama, Pendahuluan Pendidikan Agama Islam Di Perguruan Tinggi, Surabaya: PT. Bina Ilmu.

Chotib, Moch. 2010. Pesantren Dan Masyarakat Transformatif. Jember: Pena Salsabila.

Haris, Abd. dan Kivah Aha Putra. 2012, Filsafat Pendidikan Islam. Jakarta: Amzah.

Hilmy, Masdar. 2016, Pendidikan Islam dan Tradisi Ilmiah. Malang: Madani.

Ichsan, Moch. dan Anshari, Zainal 2017. Sejarah Masjid Jami' Al-Baitul Amien Jember; Mengurai Peran Dan Kontribusinya. Jember: Superior

Marinda, Leny. 2011, “implementasi pembelajaran Full Day School dalam meningkatkan kecerdasan social peserta didik di SD al-Baitul Amien Jember”, Jember: STAIN Jember. skripsi tidak dipublikasikan.

Moch. Chotib. 2010. Cakrawala Pesantren; Melacak Geneologi Pendidikan Pesantren. Jember: Pena Salsabila.

Observasi dan wawancara kepada bapak Rifan Humaidi dan ibu Nurul, Januari - Juni 2016.

Qomar, Mujammil. 2015. Dimensi Manajemen Pendidikan Islam. Jakarta: Emir-Erlangga.

Rafik, Ainur. 2013. Pendidikan Islam Dalam Sisdiknas, Jember: STAIN Jember Press.

Sallis, Edward. 2011. Total Quality Management in Education. Yogyakarta: IRCiSoD.

Sisdiknas nomor 20 tahun 2003 tentang system pendidikan nasional Indonesia.

Soebahar, Abd. Halim. 2009. Matriks Pendidikan Islam. Yogyakarta: Pustaka Marwa.

Soebahar, Abd. Halim. 2013. Modernisasi Pesantren; Studi Transformasi Kepemimpinan Kiai dan System Pendidikan Pesantren. Yogyakarta: LKIS.

Steenbrink, Karel A. 1974. Pesantren, Madrasah, Sekolah Pendidikan Islam dalam Kurun Modern. Jakarta: LP3ES.

Winoto, Suhadi. 2011. Manajemen Berbasis Sekolah. Jember: Pena Salsabila. 